\title{
Evaluation of the Knowledge of Sun Damage, Solar Protection and Skin Cancers among University Students and Their Parents
}

\author{
Ayşe Nilhan Atsü̈ ${ }^{1}$ (D) , Nazlı Caf ${ }^{2}$ (iD , Bilgen Erdoğan² (iD , Zafer Türkoğlu²
}

${ }^{1}$ Isstanbul Kent University, Faculty of Health Sciences, Istanbul, Turkey

${ }^{2}$ Başakşehir Çam and Sakura City Hospital, Department of Dermatology, Istanbul, Turkey

Ayşe Nilhan ATSÜ

Nazlı CAF

Bilgen ERDOĞAN

Zafer TÜRKOĞLU

\section{Correspondence: Nazlı Caf}

Başakşehir Çam and Sakura City Hospital, Department of Dermatology, Istanbul, Turkey

Phone: +905366391813

E-mail: naslicaf@hotmail.com

Received

\section{ABSTRACT}

Purpose: Awareness of the harmful effects of the sun, follow up of nevi, and the knowledge of solar protection are important for the prevention and early diagnosis of skin cancers. Our aim is to evaluate the knowledge of university students and their parents about the harmful effects of the sun, and associated skin cancers.

Methods: 653 university students and 615 parents participated in our cross-sectional study. The survey was delivered via the SurveyMonkey application link and demographic data was recorded. Fitzpatrick skin types, natural hair and eye colors, and personal, and family skin cancer history were questioned. Information on the harmful effects of the sun, nevus examination, self-skin examination, symptoms of skin cancers, and facilitating factors were questioned.

Results: 1004 of the participants were women, 264 were men. Fitzpatrick II skin type and brown eyes were the most common in both groups. The nevi follow-up and self-examination habits did not differ statistically between the groups. Nevi follow-up was regarded as essential and requiring a dermatologist. Participants believed that the most common skin cancer was malignant melanoma.

Conclusion: It is important to raise awareness about skin cancers, to follow up nevi and to introduce the habit of selfexamination into society in general.

Keywords: Dermatologist, Melanoma, Nevus, Preventive Medicine

Güneş Koruma ve Deri Kanserlerine Dair Farkındalığının Üniversite Öğrencileri ve Ebeveynlerinde Değerlendirilmesi

ÖZET

Amaç: Güneşin zararlı etkileri ve fotokorunmaya dair bilgi ile nevüs takibinin gerekliliğine dair farkındalık, deri kanserlerinden korunma ve erken teşhis için önemlidir. Amacımız, üniversite öğrencilerinin ve velilerinin güneşin zararlı etkileri ve deri kanserleri hakkındaki bilgilerinin değerlendirilmesidir.

Yöntem: Kesitsel çalışmamıza 653 üniversite öğrencisi ve 615 veli katıldı. Anket, SurveyMonkey uygulama bağlantısı üzerinden katıımcılara iletildi. Fitzpatrick deri tipleri, doğal saç ve göz renkleri, kişisel ve aile cilt kanseri öyküsü sorgulandı. Katılımcıların güneşin zararlı etkileri, nevüs muayenesi, kendi kendine deri muayenesi, deri kanserlerinin belirtileri ve kolaylaş̧ıııı faktörler hakkındaki bilgileri değerlendirildi.

Bulgular: Katılımcıların 1004'ü kadın, 264'ü erkekti. Her iki grupta da en yaygın Fitzpatrick II deri tipi ve kahverengi göz saptandı. Gruplar arasında nevus takibi ve kendi kendine ben muayenesi alışkanlıkları istatistiksel olarak farkılık göstermedi. Nevüs takibinin gerekli olduğu ve dermatolog tarafından yapılması gerektiği bildirildi. Katılımcılar en yaygın deri kanserinin malign melanom olduğunu bildirdi.

Sonuç: Deri kanserleri konusunda farkındalık yaratmak, nevüs takibinin öneminin altını çizmek ve topluma kendi kendine deri muayenesi alışkanlığı kazandırmak oldukça önemlidir.

Anahtar kelimeler: Dermatolog, Koruyucu Hekimlik, Melanom, Nevüs 
U Itraviolet rays have harmful effects on human skin. These rays can cause sunburns, skin cancers and aging. Accordingly, intense overexposure to sunlight causes acute sunburn leading to an erythematous skin rash, while chronic exposure leads to both photoaging of the skin and an increased risk of melanoma and non-melanoma skin cancers (1).

Keratinocyte-derived skin cancers are the most common type, but the most lethal skin cancer is malignant melanoma. The facilitating effects of sunlight on the formation of malignant melanoma and keratinocyte-derived squamous cell carcinoma (SCC) and basal cell carcinoma (BCC) are widely known. In addition, the harmful effects of the sun are not only limited to the skin but can cause some damage and diseases in the eyes such as photoconjunctivitis, cataracts and retinal degeneration. Sun rays can also cause uveal/conjunctival melanoma (2).

It has been reported that the incidence of malignant melanoma in the USA has increased by $270 \%$ in the last 30 years due to increased life expectancy and UV exposure. It is known that exposure to both natural (sunlight) or artificial UV rays such as tanning beds (solariums) may play a role in the development of melanoma. In addition, iatrogenic exposure may be given with phototherapy. All are known to increase other skin cancers such as BCC and SCC, but this association is stronger in melanoma (3). Apart from the parameters mentioned above, it should be kept in mind that some inalterable phenotypic risk factors such as light skin and eye color are also risk factors for melanoma (4). Being aware of the harmful effects of the sun and following protective behaviors in society may be important in determining future goals and creating a stronger public awareness of this issue (5).

Preventive medicine practice against skin cancers is essential and its popularity is increasing every day. In this regard, it is very important for individuals to know their own skin type and the risks associated with it, to be aware of the risk of familial skin cancer, and to be conscious of protection methods from UV rays (UVR). In addition, it should be known in society that moles on the skin and in areas such as the mouth and genital area may lead to skin cancers and should be strictly followed by a dermatologist. Therefore, the aim of this study is to compare sun awareness between university students and their parents.

\section{MATERIALS AND METHOD}

The study was planned as a cross-sectional, online survey study. Istanbul Kent University students and their parents were included in the study. In total, 653 students and 615 parents voluntarily participated in the online survey for the study. The survey was delivered to the participants via SurveyMonkey application link. Permission was obtained before starting the online survey questions, and viewing the other questions was not allowed unless the consent page was accepted.

The age and gender information of the participants who gave consent was recorded and the educational status of the participating parents was questioned. In the survey, totally 39 questions were asked to each participant about solar damage, sun protection methods and skin cancer. Personal and familial history of skin cancer of both students and parents were recorded. In the next step, to determine the skin phototypes, the question "which describes you best?" was asked and the person was asked to mark the answer that best suited them. According to the answers given, the Fitzpatrick skin type of the participants was determined, and no physician evaluation was made. Whether or not all participants were sensitive to the sun was recorded with yes/no questions. In the next step, questions evaluating the knowledge of solar damage, and skin cancer were asked, and sun protection attitudes were assessed.

\section{RESULTS}

\section{Demographic Data}

1004 of the participants were female (79.2\%), 264 were male (20.8\%), and the median age was 37 years (min-max: $18-60$ ). While $65.9 \%$ of the parents were university graduates, $20 \%$ held associate degrees, $8.3 \%$ were high school, $3.1 \%$ were secondary school, and $2.8 \%$ were primary school graduates (Table 1).

Of the parents, 133 were Fitzpatrick type I, 242 were type II, 87 were type III and 153 were type IV (21.6\%, 39.3\%, $14.1 \%$ and $24.9 \%$, respectively). Among university students, 170 were Fitzpatrick type I, 260 were type II, 73 were type III and 150 were type IV $(26.0 \%, 39.8 \%, 11.2 \%$ and $23.90 \%$, respectively).

The distribution of eye color did not differ significantly ( $p$ $>0.05$ ) between the groups. The distribution of natural hair and eye color in the two groups did not differ significantly $(p>0.05)$, and the rates of having brown eye color and dark brown hair were higher in both groups.

The rate of personal and family history of skin cancer did not differ significantly between the groups $(p>0.05$ for both). 
Table 1. Age, gender, and educational status

\begin{tabular}{|l|l|l|l|l|l|}
\hline & & Min-Max & Median & \multicolumn{2}{|c|}{ Mean.sd \pm /n-\% } \\
\hline Age & & $18.0-60.0$ & 37.0 & \multicolumn{2}{|c|}{$36.2 \pm 11.9$} \\
\hline \multirow{3}{*}{ Gender } & Female & & & 1004 & $79.2 \%$ \\
\hline & Male & & & 264 & $20.8 \%$ \\
\hline \multirow{5}{*}{ Education } & Primary & & & 17 & $2.8 \%$ \\
\cline { 2 - 6 } & Middle & & & 19 & $3.1 \%$ \\
\cline { 2 - 6 } & $\begin{array}{l}\text { High } \\
\text { School }\end{array}$ & & & 51 & $8.3 \%$ \\
\cline { 2 - 6 } & $\begin{array}{l}\text { Associate } \\
\text { degree }\end{array}$ & & & 123 & $20.0 \%$ \\
\cline { 2 - 6 } & University & & & 405 & $65.9 \%$ \\
\hline
\end{tabular}

The rate of sun sensitivity and sun protection habit with hats did not differ significantly between the groups ( $p>0.05)$. There was no significant difference in the preference of sitting in open areas and choosing shade areas in the university student and parent groups $(p>$ 0.05 ). The rate of consulting a pharmacist or social media about sunscreen products did not differ significantly $(p>$ 0.05 ) between the groups. The rate of consulting a family physician or social acquaintances about the choice of sunscreen products in the parent group was significantly higher $(p<0.05)$ than the student group. In the student group, the rate of consulting a dermatologist about sunscreen products was found to be significantly higher $(p<$ 0.05) compared to the parents (Table 2 ).
There was no significant difference $(p>0.05)$ between the groups on the knowledge about the time when the sun is strongest and whether the damage caused by the sun can be repaired. Similarly, there was no significant difference between the groups in response distributions regarding which clothes offer greater protection from UV rays and in which environments there is a risk of sunburn $(p>0.05)$.

There was no significant difference $(p>0.05)$ between the groups in determining the angle of sun rays according to the length of shade. There was no significant difference ( $p$ $>0.05$ ) between the groups in the knowledge of whether sunbathing during the summer vacations for a few days a year would increase the risk of skin cancer.

\section{Monitoring of Nevi and Evaluation of Awareness about Skin Cancer}

The rates of identifying regular nevi follow-up as necessary and self-examination habits did not differ significantly between the groups ( $p>0.05)$. Opinions about which physician should follow up the moles on the body did not differ significantly between the groups $(p>0.05)$, and the requirement for dermatologist follow-up was answered correctly at a high rate (students: $82.4 \%$ and parents: $77.6 \%$ ) (Table 3).

Table 2. Getting information about sun protection preferences and sunscreen products

\begin{tabular}{|c|c|c|c|c|c|c|}
\hline & \multicolumn{2}{|c|}{ Student } & \multicolumn{2}{|c|}{ Parent } & \multirow{2}{*}{\multicolumn{2}{|c|}{ p }} \\
\hline & $\mathbf{n}$ & $\%$ & $\mathbf{n}$ & $\%$ & & \\
\hline \multicolumn{7}{|c|}{ Do you have sun sensitivity? } \\
\hline Yes & 310 & $47.5 \%$ & 262 & $42.6 \%$ & \multirow{2}{*}{0.081} & \multirow{2}{*}{$x^{2}$} \\
\hline No & 343 & $52.5 \%$ & 353 & $57.4 \%$ & & \\
\hline \multicolumn{7}{|c|}{ Do you have a habit of protecting yourself from the sun with a hat? } \\
\hline Yes & 336 & $51.5 \%$ & 344 & $55.9 \%$ & \multirow{2}{*}{0.110} & \multirow{2}{*}{$X^{2}$} \\
\hline No & 317 & $48.5 \%$ & 271 & $44.1 \%$ & & \\
\hline \multicolumn{7}{|c|}{ Would you prefer to sit in shade when sitting outside? } \\
\hline Yes & 594 & $91.0 \%$ & 555 & $90.2 \%$ & \multirow{2}{*}{0.660} & \multirow{2}{*}{$\mathrm{X}^{2}$} \\
\hline No & 59 & $9.0 \%$ & 60 & $9.8 \%$ & & \\
\hline \multicolumn{7}{|c|}{ Who do you consult about sunscreen products? } \\
\hline Pharmacist & 182 & $27.9 \%$ & 174 & $28.3 \%$ & 0.916 & $x^{2}$ \\
\hline Family Physician & 46 & $7.0 \%$ & 99 & $16.1 \%$ & 0.000 & $x^{2}$ \\
\hline Dermatologist & 289 & $44.3 \%$ & 177 & $28.8 \%$ & 0.000 & $x^{2}$ \\
\hline Social Media/YouTube & 62 & $9.5 \%$ & 62 & $10.1 \%$ & 0.797 & $X^{2}$ \\
\hline Social Acquaintances & 74 & $11.3 \%$ & 103 & $16.7 \%$ & 0.007 & $x^{2}$ \\
\hline
\end{tabular}


Table 3. Evaluation of awareness about moles follow-up on the body

\begin{tabular}{|c|c|c|c|c|c|c|}
\hline & \multicolumn{2}{|c|}{ Student } & \multicolumn{2}{|c|}{ Parent } & \multirow{2}{*}{\multicolumn{2}{|c|}{$\mathbf{p}$}} \\
\hline & $\mathbf{n}$ & $\%$ & $\mathbf{n}$ & $\%$ & & \\
\hline \multicolumn{7}{|c|}{ Is it necessary to follow-up the moles? } \\
\hline Yes & 598 & $91.6 \%$ & 545 & $88.6 \%$ & \multirow{2}{*}{0.077} & \multirow{2}{*}{$X^{2}$} \\
\hline No & 55 & $8.4 \%$ & 70 & $11.4 \%$ & & \\
\hline \multicolumn{7}{|c|}{ Do you have the habit of skin self-examination? } \\
\hline Yes & 242 & $37.1 \%$ & 240 & $39.0 \%$ & \multirow{2}{*}{0.471} & \multirow{2}{*}{$X^{2}$} \\
\hline No & 411 & $62.9 \%$ & 375 & $61.0 \%$ & & \\
\hline \multicolumn{7}{|c|}{ Which specialist follows-up the moles on the body? } \\
\hline Family physician & 30 & $4.6 \%$ & 25 & $4.1 \%$ & \multirow{4}{*}{0.064} & $\mathrm{X}^{2}$ \\
\hline Internal specialist & 50 & $7.7 \%$ & 71 & $11.5 \%$ & & $x^{2}$ \\
\hline General surgeon & 35 & $5.4 \%$ & 42 & $6.8 \%$ & & $x^{2}$ \\
\hline Dermatologist & 538 & $82.4 \%$ & 477 & $77.6 \%$ & & $x^{2}$ \\
\hline
\end{tabular}

Evaluation of Awareness about Moles Follow-up on the Body There was no significant difference $(p>0.05)$ within the groups regarding the opinions that "dark-skinned people will never have skin cancer" and "excessive exposure to the sun is the only way for a person to get skin cancer" ( $p$ $>0.05$ for both). When the most common skin cancer was questioned in both groups, there was no statistical difference between the answers given and the most common answer was "melanoma" ( $p>0.05)$. There was no significant difference in knowledge level between the groups in terms of symptoms of skin cancer $(p>0.05)$.

\section{Evaluation of Sun Protection Measures}

The response rate to the question of whether the habit of using sunglasses is essential or necessary for protection against UV rays of the sun did not differ significantly $(p>$ 0.05 ) between the groups. Knowledge of the presence of sunscreen and UV filtered clothing did not differ significantly between the groups ( $p>0.05)$.

There was no significant difference between the groups in the response rates on whether tanning with a solarium is safe $(p>0.05)$. The answers given to the statements "it is possible to tan without any negative effects when sunscreen cream/spray is applied" and "tanning protects my skin against the harmful effects of sun" did not differ significantly between the two groups ( $p>0.05$ for both).
Among the questions given in Table 4, only the opinion on whether gradual tanning removes the harmful effects of the sun was statistically significant between the groups. The awareness rate of this proposition, which is known to be false, was found to be higher in university students compared to parents $(p=0.012)$.

It was determined that the knowledge and attitudes regarding the correct timing of sunscreen use were not statistically significant between the groups, and the accuracy rates were high in both groups ( $p>0.05)$ (Table 5).

Participants have knowledge that both having a severe sunburn and having a family history of skin cancer increase the risk of skin cancer. However, the knowledge that having both sunburn and a family history of skin cancer increase the risk separately was found to be statistically higher in the student group compared to the parents. Alterations in the existing nevi and non-healing wounds, which are symptoms of skin cancer, are concepts that are well known in both groups, and no statistical difference was observed (Table 6). 
Table 4. Information on Artificial Tanning Beds

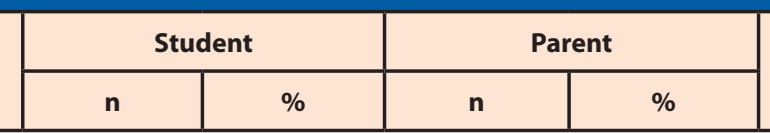

p

Tanning beds are safe to get a tan

\begin{tabular}{|c|c|c|c|c|c|c|}
\hline True & 62 & $9.5 \%$ & 62 & $10.1 \%$ & \multirow{2}{*}{0.725} & \multirow{2}{*}{$\mathrm{X}^{2}$} \\
\hline False & 591 & $90.5 \%$ & 553 & $89.9 \%$ & & \\
\hline \multicolumn{7}{|c|}{ It is possible to get a tan without any negative effects when using sunscreen cream/spray } \\
\hline True & 281 & $43.0 \%$ & 286 & $46.5 \%$ & \multirow{2}{*}{0.214} & \\
\hline False & 372 & $57.0 \%$ & 329 & $53.5 \%$ & & \\
\hline \multicolumn{7}{|c|}{ Tanning protects my skin against the sun } \\
\hline True & 203 & $31.1 \%$ & 187 & $30.4 \%$ & \multirow{2}{*}{0.793} & \\
\hline False & 450 & $68.9 \%$ & 428 & $69.6 \%$ & & \\
\hline
\end{tabular}

Bronzing sprays provide no sun protection

\begin{tabular}{|l|c|c|c|c|c|}
\hline True & 287 & $44.0 \%$ & 250 & $40.7 \%$ & 0.235 \\
\cline { 1 - 3 } & $\mathrm{X}^{2}$ & 365 & $59.3 \%$ & 0 \\
\hline
\end{tabular}

Tanning with tanning beds (solariums) in winter protects the skin against sun damage in summer

\begin{tabular}{|l|c|c|c|c|c|}
\hline True & 125 & $19.1 \%$ & 140 & $22.8 \%$ & 0.113 \\
\hline False & 528 & $80.9 \%$ & 475 & $77.2 \%$ & $X^{2}$ \\
\hline
\end{tabular}

Gradual tanning eliminates most of the negative effects of prolonged sun exposure

\begin{tabular}{|l|l|l|l|l|l|l|}
\hline True & 494 & $75.7 \%$ & 501 & $81.5 \%$ & $\mathbf{0 . 0 1 2}$ & $X^{2}$ \\
\cline { 1 - 5 } False & 159 & $24.3 \%$ & 114 & $18.5 \%$ & $\mathbf{0 . 0 1 2}$ \\
\hline
\end{tabular}

Tanning is a sign of skin damage

\begin{tabular}{|l|l|l|l|l|l|l|}
\hline True & 248 & $38.0 \%$ & 233 & $37.9 \%$ & \multirow{2}{*}{0.973} & $X^{2}$ \\
\cline { 1 - 6 } False & 405 & $62.0 \%$ & 382 & $62.1 \%$ & \\
\hline
\end{tabular}

UVR from tanning beds are safer than UVR from the sunlight

\begin{tabular}{|l|c|c|c|c|c|}
\hline True & 134 & $20.5 \%$ & 122 & $19.8 \%$ & 0.762 \\
\hline False & 519 & $79.5 \%$ & 493 & $80.2 \%$ & $X^{2}$ \\
\hline
\end{tabular}

Tanning is an unsafe way to get the vitamin $D$ that your body needs

\begin{tabular}{|l|c|c|c|c|c|c|c|}
\hline True & 355 & $54.4 \%$ & 311 & $50.6 \%$ & 0.176 & $X^{2}$ \\
\hline False & 298 & $45.6 \%$ & 304 & $49.4 \%$ & \multicolumn{2}{|l|}{304} \\
\hline Tanning is a sign of physical health & 251 & $38.4 \%$ & 232 & $37.7 \%$ & 0.793 & $X^{2}$ \\
\hline True & 402 & $61.6 \%$ & 383 & $62.3 \%$ & \\
\hline False &
\end{tabular}

If you don't usually get sun exposure, getting two or three severe sunburns in your life probably won't increase your chances of skin cancer

\begin{tabular}{|l|l|l|l|l|l|}
\hline True & 276 & $42.3 \%$ & 234 & $38.0 \%$ & 0.126 \\
\hline False & 377 & $57.7 \%$ & 381 & $62.0 \%$ & $X^{2}$ \\
\hline$X^{2}$ Chi-square test & \\
\hline
\end{tabular}


Table 5. Evaluation of Timing Regarding the Use of Sunscreen Creams

\begin{tabular}{|c|c|c|c|c|c|c|}
\hline & \multicolumn{2}{|c|}{ Student } & \multicolumn{2}{|c|}{ Parent } & \multirow{2}{*}{\multicolumn{2}{|c|}{$\mathbf{p}$}} \\
\hline & $\mathbf{n}$ & $\%$ & $\mathbf{n}$ & $\%$ & & \\
\hline \multicolumn{7}{|l|}{ When to apply sunscreen for best protection? } \\
\hline Just before exposure to the sun & 89 & $13.6 \%$ & 93 & $15.1 \%$ & \multirow{3}{*}{0.573} & \multirow{3}{*}{$x^{2}$} \\
\hline 15-30 minutes before sun exposure & 546 & $83.6 \%$ & 501 & $81.5 \%$ & & \\
\hline Within 15-30 minutes after sun exposure & 18 & $2.8 \%$ & 21 & $3.4 \%$ & & \\
\hline \multicolumn{7}{|c|}{ How often should sun protection factor (SPF) $\mathbf{3 0}$ sunscreen should be reapplied? } \\
\hline In every 30 minutes & 150 & $23.0 \%$ & 134 & $21.8 \%$ & \multirow{3}{*}{0.153} & \multirow{3}{*}{$\mathrm{X}^{2}$} \\
\hline $\begin{array}{l}\text { In every 2-3 hours and more often when swimming or } \\
\text { sweating }\end{array}$ & 433 & $66.3 \%$ & 393 & $63.9 \%$ & & \\
\hline None of the above & 70 & $10.7 \%$ & 88 & $14.3 \%$ & & \\
\hline
\end{tabular}

\section{Table 6. Awareness of Skin Cancers}

\begin{tabular}{|c|c|c|c|}
\hline \multicolumn{2}{|c|}{ Student } & \multicolumn{2}{c|}{ Parent } \\
\hline $\mathbf{n}$ & $\%$ & $\mathbf{n}$ & $\%$ \\
\hline
\end{tabular}

\section{Dark-skinned people do not have skin cancer}

\begin{tabular}{|c|c|c|c|c|c|c|}
\hline True & 34 & $5.2 \%$ & 39 & $6.3 \%$ & \multirow{2}{*}{0.386} & \multirow{2}{*}{$X^{2}$} \\
\hline False & 619 & $94.8 \%$ & 576 & $93.7 \%$ & & \\
\hline \multicolumn{7}{|c|}{ The only way a person can get skin cancer is overexposure to sun } \\
\hline True & 94 & $14.4 \%$ & 111 & $18.0 \%$ & \multirow{2}{*}{0.077} & \multirow{2}{*}{$X^{2}$} \\
\hline False & 559 & $85.6 \%$ & 504 & $82.0 \%$ & & \\
\hline \multicolumn{7}{|l|}{ Which of the following increases your risk of skin cancer? } \\
\hline Three severe sunburns in the past & 54 & $8.3 \%$ & 76 & $12.4 \%$ & 0.021 & $X^{2}$ \\
\hline Having a family history of skin cancer & 182 & $27.9 \%$ & 198 & $32.2 \%$ & 0.105 & $\mathrm{X}^{2}$ \\
\hline Both options above & 390 & $59.7 \%$ & 313 & $50.9 \%$ & 0.002 & $X^{2}$ \\
\hline None of the above & 27 & $4.1 \%$ & 28 & $4.6 \%$ & 0.820 & $X^{2}$ \\
\hline \multicolumn{7}{|l|}{ What is the most common type of skin cancer? } \\
\hline Malign Melanoma & 313 & $47.9 \%$ & 284 & $46.2 \%$ & \multirow{4}{*}{0.508} & \multirow{4}{*}{$\mathrm{X}^{2}$} \\
\hline Basal Cell Carcinoma & 146 & $22.4 \%$ & 125 & $20.3 \%$ & & \\
\hline Squamous Cell Carcinoma & 87 & $13.3 \%$ & 95 & $15.4 \%$ & & \\
\hline None of the above & 107 & $16.4 \%$ & 111 & $18.0 \%$ & & \\
\hline \multicolumn{7}{|l|}{ Which of the following may be a sign of skin cancer? } \\
\hline A sudden or gradual change in the appearance of a mole & 177 & $27.1 \%$ & 175 & $28.5 \%$ & \multirow{4}{*}{0.549} & \multirow{4}{*}{$\mathrm{X}^{2}$} \\
\hline A wound that does not heal & 83 & $12.7 \%$ & 91 & $14.8 \%$ & & \\
\hline Both options above & 359 & $55.0 \%$ & 315 & $51.2 \%$ & & \\
\hline None of the above & 34 & $5.2 \%$ & 34 & $5.5 \%$ & & \\
\hline
\end{tabular}




\section{DISCUSSION}

It has been reported that skin cancers increase every year in epidemiological studies. Between 2001 and 2010, there was an annual increase of at least $1.6 \%$ new incidence. In addition, it has been emphasized that the rates of nonmelanoma skin cancers (NMSCs) have increased by $77 \%$ in the last 20 years, and malignant melanoma has increased by at least $250 \%$ in the last 40 years in young adulthood, adolescence and childhood (6). Due to the increasing frequency, it is very important to be aware of the harmful effects of the sun and to be aware of protection measures. As far as we know, no study has been conducted in Turkey comparing these knowledge and protection attitudes among university students and their parents. However, in a survey conducted by Selçuk et al. in 2019, university students aged 18-26 were evaluated and sun protection behaviors such as wearing hats, wearing long sleeves, using sunglasses and preferring to sit in the shade were evaluated, and it was reported that the participants had high sun protection rates, especially in medical students (7).

Due to the increase in the use of social media and the ease of access to information today, it can be thought that university students have higher knowledge of sun damage and protection attitudes compared to their parents. However, in this study, parents' knowledge, and protective attitudes against the harmful effects of the sun were found to be similar to those of university students in most parameters. This may be due to the fact that this age population also uses social media more actively today and makes use of resources such as conventional media methods.

In a cross-sectional study conducted with university students in Brazil, although sun awareness was found to be higher in health sciences faculties compared to other faculties, it was reported that all participants had sufficient awareness. However, despite the fact that the information questioned in this study is very basic, it has been emphasized that $10 \%$ of the population still does not have sufficient information. In addition, although skin cancer and sun damage are known, the frequency of use of sunscreen methods was found to be quite low, and it was found that only one third of the participants used sunscreen regularly (8). Since our study does not only measure the knowledge and protection levels of university students, but also compares this information with their parents, it is not very appropriate to make these inferences. However, the knowledge of university students regarding the harmful effects of the sun is generally sufficient. The group selected in our study was not exclusively selected from medical branches but is a heterogeneous group that includes all faculties. The knowledge of the individuals participating in our study about the harmful effects of the sun showed different results in different questions and can be interpreted as medium-high in general.

In this study, both university students and their parents were found to be highly aware of the need to monitor their nevi and to consult a dermatologist in this regard. However, the rates of skin self-examination habits in both parent and student groups were quite low (parents: 39\%, students: $37.1 \%)$. Self-examination for breast cancer has become very popular and practiced across society. The internet, conventional media organizations, social media and patient schools have played an important role in obtaining these results (9). However, skin self-examination is not a known and prominent concept today. In a study conducted in 2013 , it was determined that only $22 \%$ of the participants in all age groups performed annual skin self-examination (10). Although the rates are observed to have increased compared to this year in this study, we still think that it is not an adequate rate. In a study conducted of adolescents in Northern Cyprus in 2019, it was reported that skin self-examination was performed by $39.8 \%$ of 163 participants, and was higher in women (11). It has been reported that sensitivity in skin self-examination is between $25 \%$ and $93 \%$, but these studies are not randomized-controlled studies (12). Although it has been reported that this examination can be facilitated with mobile phone applications, it has been shown in a randomizedcontrolled study conducted in Australia that mobile phone applications are not superior to self-examination with naked eye (12). We think that it is necessary to organize community-based education studies and patient schools on skin self-examination. Thus, earlier diagnosis and better response to treatment of skin cancers will be possible and morbidity, mortality and economic burdens related to these diseases will decrease. 
Today, with the increasing frequency of social media use and the concern of looking more beautiful and aesthetic, artificial tanning such as solariums and natural tanning such as sunbathing have become increasingly popular among the young population. There is an increasing amount of data showing that the facial appearance of a person significantly affects factors such as personality and attractiveness perception (13). People now use social media platforms such as Instagram more often than other communication methods. The rate of use of these platforms can reach $90 \%$, especially among young individuals between the ages of 18-29, and different photos and content are watched continuously or intermittently. Trends such as looking slimmer are increasing day by day on social media platforms and can lead to a number of consequences such as body dissatisfaction (14). In a study, $80 \%$ of young adults between the ages of 18 and 25 who used tanning beds regularly or intermittently used Facebook, 30\% regularly or intermittently used Twitter and Instagram platforms, and those who regularly used Instagram and Twitter had higher rates of tanning bed use (15). In addition, it was emphasized that advertising on these platforms to promote artificial tanning is also legal in some countries and the view that this may increase use should not be ignored (16). In this study, data on advertisements promoting artificial tanning were not evaluated. In addition, individuals were not questioned about their artificial tanning habits, but only whether they were aware of the harms of these methods. In the study, students were expected to have higher awareness than their parents. However, the opinion that a solarium is harmful was not found to be statistically significant between the two groups. However, the statement "it is possible to get a tan without any negative effects while using sunscreen" was not commented on correctly at a high rate, like the previous statement, and there is no statistical difference between the two groups. It shows that dermatologists should also contribute to education in these age groups as a preventive medicine duty. In addition, the idea that "gradual tanning removes most of the negative effects of long-term sun exposure" was positively received in both groups. In order to replace this knowledge, family physicians, especially dermatologists, and all branches that take an active role in preventive medicine have important responsibilities.

The questions evaluating the timing and frequency of application of sun protection creams were answered correctly by $81.5 \%$ and $83.6 \%$ of both parents and students, respectively, and there was no statistical difference between the groups. In addition, the participants answered with high accuracy that the frequency of sunscreen should be repeated every 2-3 hours during the day and that it should be applied more frequently with sweating and swimming (parents: $63.9 \%$, student: $66.3 \%$ ), and there was no statistical difference between them. However, the applicability of this correct information by these people was not evaluated in this study, which is one of the limitations. Although the level of knowledge is high, the participants may not be using sunscreens correctly. While this situation may be caused by reasons such as cost, it may also be due to not completely understanding the extent of sun damage.

In our study, information about sun damage was determined at various levels in both groups. For example, participants believe that gradual tanning protects against the harmful effects of the sun and that tanning is an indicator of health. In addition, the number of people who think that tanning is necessary to meet their vitamin $D$ needs has been determined at a very high rate. Moreover, protection attitudes such as wearing a hat, using sunglasses, or preferring the shade of the umbrellas in outdoor areas were also evaluated as moderately high. Although the participants knew that their nevi should be followed up by a dermatologist, the rate of skin self-examination was not very high. The rate of consulting a dermatologist on sunscreen products was found to be significantly higher in the university student group compared to parents. Necessary educations and workshops should be conducted in order to increase the rate of application to the right resources for the parent group in terms of choosing the right sunscreen products.

To acquire sun protection habits, it is important to give education at earlier levels, especially at primary school ages. However, according to the data obtained from the study, some misconceptions and misinformation about the harmful effects of the sun and protection persist among university students. For this reason, we are of the opinion that it is not late, and even necessary, to provide relevant education at these ages. In addition, it is very important to determine whether sunscreen usage habits are governed by cost or incomplete information in further studies.

\section{CONCLUSION}

Since this study is an online survey based on personal reporting, it does not include an objective physician evaluation. This is especially valid for determining the Fitzpatrick skin type. In addition, considering the cross-sectional 
nature of the study, it is not correct to make inferences about causality. In this study, it is not known at what age the individuals who say they have the habit and awareness of sun protection implement these practices, and whether they apply them in every situation. Large-scale and multi-center studies are required to determine these issues.

\section{DECLARATIONS}

Acknowledgements: None

\section{Funding: None}

Conflict of interest: All authors declare that there is no conflict of interest.

Ethical approval: All protocols for this study were approved by the Istanbul Kent University Ethics Committee (Decision No: 2020-07).

Authors contributions: Establishing the main idea and hypothesis of the study: A.N.A and N.C; Developing the hypothesis and designing the materials and methods section: A.N.A and N.C.; Evaluation of data: A.N.A, Z.T and N.C.; Writing the introductory part of the article: A.N.A and B.E. ;Writing the conclusion and discussion sections of the article: A.N.A, B.E, Z.T and N.C.; Writing the draft of the article: B.E, Z.T.; Assessing the final version of the article and making necessary corrections: A.N.A, Z.T, B.E and N.C

Availability of data: Available upon request

\section{REFERENCES}

1. Biesalski HK, Obermueller-Jevic UC. UV light, beta-carotene and human skin - Beneficial and potentially harmful effects. Arch Biochem Biophys. 2001;389 (1):1-6.

2. Alfredsson L, Armstrong BK, Allan Butterfield D, Chowdhury R, de Gruijl FR, Feelisch M, et al. Insufficient sun exposure has become a real public health problem. Int J Environ Res Public Health. 2020;17 (14):1-15

3. Carr S, Smith C, Wernberg J. Epidemiology and Risk Factors of Melanoma. Surg Clin North Am [Internet]. 2020;100 (1):1-12. Available from: https://doi.org/10.1016/j.suc.2019.09.005

4. Marianne Berwick, David B. Buller, Anne Cust RG, Tim K. Lee, Frank Meyskens, Shaily Pandey NET, Ward MBV and S. Melanoma Epidemiology and Prevention. In: Mehnert HLKM, editor. Melanoma. 1st ed. Springer, Cham; 2016. p. 17-49.

5. Holman DM, Ding H, Guy GP, Watson M, Hartman AM, Perna FM. Prevalence of sun protection use and sunburn and association of demographic and behaviorial characteristics with sunburn among US adults. JAMA Dermatology. 2018;154 (5):561-8.

6. O'Neill CH, Scoggins CR. Melanoma. J Surg Oncol [Internet]. 2019;120 (5):873-81. Available from: http://dx.doi.org/10.1002/jso.25604
7. Baykal Selcuk L, Aksu Arica D, Ates E, Yayli S, Bahadir S. Sun-protective behaviours of Turkish young adults. Photodermatol Photoimmunol Photomed. 2019;35 (3):178-86.

8. Dallazem LND, Benvegnú AM, Stramari JM, Beber AAC, Chemello $R M L$, Beck M de O. Knowledge and habits of sun exposure in university students: a cross-sectional study in Southern Brazil. An Bras Dermatol. 2019;94 (2):172-81.

9. Alhawamdeh AK. The Relationship Between Media Marketing Advertising and Encouraging Jordanian Women to Conduct Early Detection of Breast Cancer. Eur J Bus Manag. 2020;130-5.

10. Carly Roman, Aida Lugo-Somolinos NT. Skin Cancer Knowledge and Skin Self-examinations in the Hispanic Population of North Carolina: The Patient's Perspective. JAMA Dermatology. 2013;149 (10):103-4.

11. Mullaaziz D, Kaptanoğlu A, Hinçal E, Çalikoğlu EE. Investigation of skin self-examination and sunscreen use in adolescents in northern Cyprus. Postep Dermatologii i Alergol. 2021;38 (3):505-9.

12. Janda M, Horsham C, Vagenas D, Loescher LJ, Gillespie N, Koh $\mathrm{U}$, et al. Accuracy of mobile digital teledermoscopy for skin selfexaminations in adults at high risk of skin cancer: an open-label, randomised controlled trial. Lancet Digit Heal [Internet]. 2020;2 (3):e129-37. Available from: http://dx.doi.org/10.1016/S2589-7500 (20)30001-7

13. Eggerstedt M, Rhee J, Urban MJ, Mangahas A, Smith RM, Revenaugh PC. Beauty is in the eye of the follower: Facial aesthetics in the age of social media. Am J Otolaryngol - Head Neck Med Surg [Internet]. 2020;41 (6):102643. Available from: https://doi.org/10.1016/j. amjoto.2020.102643

14. Aparicio-Martinez P, Perea-Moreno AJ, Martinez-Jimenez MP, RedelMacías MD, Pagliari C, Vaquero-Abellan M. Social media, thin-ideal, body dissatisfaction and disordered eating attitudes: An exploratory analysis. Int J Environ Res Public Health. 2019;16 (21).

15. Stapleton, Jerod L.; Hillhouse, Joel; Coups, Elliot J.; Pagoto S. Social media use and indoor tanning among a national sample of young adult nonHispanic white women: A cross-sectional study. J Am Acad Dermatol. 2016;75 (1):218-220.

16. Abbott LM, Byth $K$, Fernandez-Penas P. Tanning, selfies and social media. Australas J Dermatol. 2019;60 (1):82-4. 